\title{
The Earliest Placenames in Jamaica
}

\section{Frederic G. Cassidy}

Jamaica, West Indies, should be of onomastic interest because early conferral of the names exemplifies naming-patterns that are fairly typical of the Caribbean area as a whole. The American Indian names came first, of course, Arawak and Carib. European explorers and colonists adopted and adapted some of these, added many of their own, and then, as a result of struggles among themselves, altered some names when the territories changed hands among the Europeans. One can see a common practice for name-giving in three main phases, or as three chronological layers: the Indian names, the Spanish or other European names, and the later-come European names - in the case of Jamaica, English.

The island was discovered by Columbus on his second voyage, May 4th, 1494, in the full growth of spring. He described it as "darkly green Xamayca...the fairest island that eyes have beheld." Though there was always talk of gold and copper mines the Spaniard, failing to find precious metals and seeing the unusual fertility of the island, began to settle and develop it as a source of food stuffs for their other colonies. They easily subdued the Arawak Indians and sought to Christianize them. They also sought to make them agricultural laborers, but the Arawak resisted this; their numbers dwindled and many took their own lives by drinking bitter cassava. Negroes were first imported as domestic slaves after 1513, and later as agricultural slaves.

They had been in the island for more than a century before the English took it in 1655. Those blacks who escaped to the hills and lived as "Maroons," and their descendants, formed a fourth source of a few Jamaican names - West African languages and creole English.

In the King of Spain's correspondence of the years 1519 to 1526 there are repeated references to "the Island of St. Iago, called Jamaica," which phrase seems to express a royal preference for St. Iago. Despite this, the name had little use and never appears on a map in this use. Jamaica followed Columbus' form of the name, and perhaps for that very reason ul- 
timately won out. But it had to go through many variant spellings before becoming established in its present form.

Columbus' initial $X$ must have represented an Arawak front spirant sound very much like [ $]$ ] or [c], which was its Spanish value at the timemuch the same as that of the letter $J$, which was in any case simply a scribal variant of $I$. Reading any of these in Spanish one would say [ça'maika]; on the other hand, if the map was done in Latin, it would be [ja'meika]. Later, Englishmen would read the $I$ or $J$ as $[d]$ ]: [ $d^{\prime \prime} \partial$ meik $\left.\partial\right]$, suiting their value of the letter; and Frenchmen would make it [ 3 ], as it still is in La Jamaique. The same sound-values are illustrated today by the two spellings of Mexico and Mejico, one English, the other Spanish.

As to the latter consonant, it was always [k], though spelled with $c h$, $q u$, or $c$. The mapmakers very early settled on $c$ : the full modern form first appeared in 1512 on Peter Martyr's map and thereafter rapidly superseded others. Immediately after the English conquest, in the correspondence of English officials who had evidently heard the name but not seen it written, we find curious phonetic spellings, and as late as 1690, Coronelli's Italian spelling Giamaca.

What did the name Jamaica mean? There can be little doubt that it was Arawak, since Columbus got it from these Indians at the time of his discovery. But the actual etymology remains in doubt. James Knight, in 1742, wrote, "In the original it was Jamajaco. Jamo in the Indian language is a country and Jaco is water." On this basis, and with some poetic burnishing, it is now usually rendered as "Island of Springs." If the last syllable is a form of cay, which survives today in many Jamaican place-names and is the same word as Floridian key, it comes fron Arawak (Taino) by way of Spanish cayo. This would account for the island part, but the first element is still uncertain.

Two other explanations may be quickly dismissed: Moll's map of 1708 states that the island was first called St. Jago by Columbus but later changed by the English to honor James, Duke of York, later King James II. This is remarkably unhistorical. The other was put forward by the historian Edward Long in 1774: "It is not improbable that Jamaica is a name of Indian extraction, perhaps derived from Jamacaru, the Brasilian name of the prickly-pear, which over-spreads the maritime parts of the southside, where the aboriginal Indian discoverers of this island might have first landed." This seems to be no more than a guess; a Tupì word is unlikely to have been current in Jamaica in 1494.

\section{Cassidy}




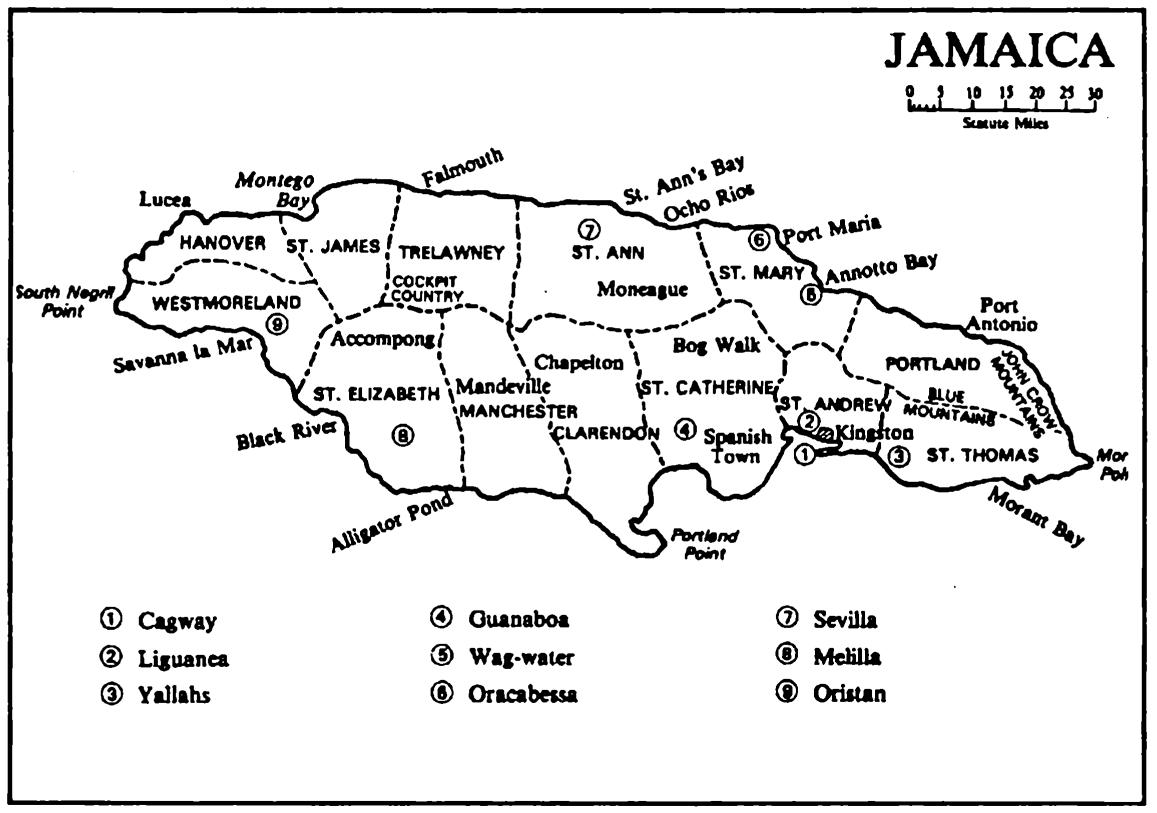

Fig. 1. Map of Jamaica. Courtesy of Cartographic Laboratory, University of Wisconsin.

The other names probable or certainly Arawakan are few, but even those few do not all appear on the early maps, and most were pretty thoroughly disguised, first by the Spanish and then by the English. The namers were not students of Indian languages. In the absence of careful observation, monolinguals are tempted to hear things in terms of the only language they know, rationalizing without adequate data and producing "popular etymologies." Jamaican names furnish some remarkable examples of this.

Navassa having been placed on one of the earliest maps, is continued, with minor differences of spelling, for a large key off the northeast end of the island, now a U.S. possession, but formerly associated with Jamaica. Though probably Arawak, the meaning is unknown. The spelling, with double $s$, would seem English rather than Spanish.

Cagway is the English rendering of Spanish Caguay or Caguaya. The Spanish forms suffered when, on some maps, an $I$ was substituted for $C$, and one map further changed the $C$ to $L$, Laguia, perhaps taking $l a$ as the article for a noun guia. The English spelling further rationalizes the end 
of the name -way, and perhaps cag-was understood, in the contemporary pronunciation, as what we call a keg today-thus, a place or road for transporting kegs. But when the point was fortified as Passage Fort, about 1660 (it first appears on Hickeringill's map of 1661) Cagway was soon superseded. Caguay or Caguaya is very probably Arawak, but the meaning is uncertain.

Wag-Water furnishes one of the most surprising developments. Guaiguata is on 16th century maps for a port and then the river flowing into it. But attempts to rationalize it produce the Spanish-like Agua Alta (deep water), and later the English took the second part of the word, -guata, very simply, as water, and Guaig-could easily produce Wag-. This could then be taken, by folk-etymology, to explain the remaining Wag as referring to the erratic course of the river or its twisting currents. Again, we do not know what the Arawaks meant by the name, and the Spanish may have accepted it simply as a name, without explanation. Guai- is a common first element in many Indian tribal names of the Caribbean and South America.

Guanaboa is more certain - at least the name is also found in the neighboring island of Hispaniola. Cundall (Place-Names) suggests with some hesitation a possible connection with guanabana, the soursop, an annonaceous fruit common in the island; but he seems to prefer the Haitian Arawak possibility, which might be translated "house of gold." The place itself was not a town but a district, and it is possible the Spaniards hoped to find gold there. If so, they were disappointed.

Oracabessa shows the apparently irresistible effect of coincidence. The Arawak form was written by the Spanish as Juracabes, with an ending very similar to Spanish cabeza, 'head' or 'headland'. If this was accepted, what did Jura- mean? The historian Edward Long made it Aura, air or breeze, hence "windy headland. Others have seen Spanish oro, 'gold' as the first element. Hickeringill (1661) at least records the initial spirant (Hora-for Jura- ) though if he thought of Spanish hora, 'hour' 'time,' it makes little sense with cabeza. Juracabes is very probably Arawak, but of unknown meaning.

Liguanea, the plain in which Kingston stands, has traditionally been taken to be connected with the iguana - a green lizard of the kind quite common in the Island, and now called by the Jamaican folk guana. A picture of the lizard has been the symbol of Liguanea for over a century. As originally the name of a ranch (hato), Liguanea may well represent a place 
where lizards were plentiful. Arawak iwana, in Spanish la iguana, is therefore a possible source, but the date of first map record is relatively late, and there were no Arawaks left in Jamaica by 1655 . This name may have been only in oral use until it was given to the ranch and so recorded. Thus, though the word was Arawak, the name and the naming were probably Spanish. The final -ea appears to be a Latinized naming element meaning something like "place," hence translatable as "Iguana-land." The Spanish

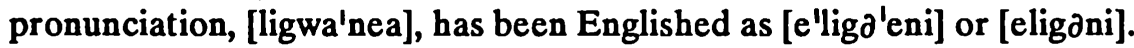

The earliest Spanish names were Sevilla, Melilla, Oristan, Negrillo, and Morante. Of these only the latter two survive in English forms as Morant Point, Morant Bay, Port Morant, and Negril - at opposite ends of the Island, both points being of essential importance for navigation, and both now having lighthouses.

Sevilla, the first capital, proved to be unhealthily located, and was moved. Melilla was also supposed to be a town, but did not flourish and was even mislocated on at least one map. Oristan was also misplaced-it was in any case not a town but a district name for the Southwestern area now including Savanna la Mar and Bluefields. The Spanish, again for reasons of health, moved the capital to Villa de la Vega (sometimes misnamed St. Iago de la Vega) but after the conquest the English found this too much of a mouthful and simply called it Spanish Town - and so it has remained, though the English moved the capital to Kingston, a new town, after the Port Royal earthquake of 1692.

Sevilla and Morante were transported Spanish placenames; Oristan was named after a town in Sardinia, then subject to the crown of Spain, and Melilla similarly for a town on the Barbary coast, then subject to Spain. Negrillo, which means black silver ore, probably reflects a hope that precious metal might be found there.

Port Antonio seems to be an English version, perhaps a conscious attempt to hispanize. In its Spanish forms it did not have the final -o, but the English frequently ended Spanish loan-words with - $o$ (for example in ambuscado, palisado, etc.). The pronunciation without -o, "Port Antóni" is still current locally.

Ocho Rios is another English remaking of a Spanish name by drastic alteration. Las Chorreras, spouts or waterfalls, which perfectly describes the spot, was made first into Ocho Rio, and then "corrected" to Ocho Rios. Several streams do indeed come down to the sea here, and people will say that eight is just the right number, but that is an ex-post- 
facto count, made to justify the name. At least, the English knew the name was Spanish, even if they got it quite wrong.

Yallahs has gone through two distinct changes, first in Spanish from Aguaia, perhaps Arawak, to Ayala, then in English to Yallahs, which was for a time understood, following a common pronunciation, as Yellow River and district. Again, there is nothing especially yellow about the area, but the foreign form seemed to call for some rationalization.

Montego Bay-despite the Spanish Monterias, of uncertain meaning and perhaps an error, is agreed to be from Spanish manteca, 'lard', which was much in demand by ships, and was obtained by the buccaneers (literally, "meat-curers") from numerous wild pigs and pigs kept in "crawls" in the interior of the Island, especially in the western part. Passing ships stopped at "Lard Bay" knowing that they could obtain lard and boucanned meat.

The English conquest of Jamaica was a series of mistakes. A fleet sent by Cromwell was intended to take Santa Domingo, but it was driven off. Not to return empty-handed, it turned to Jamaica, with its small population poorly defended. The English, under Admirals Penn and Venables, landed at the west end of present Kingston Harbor, not far from the capital, Villa de la Vega. Under the Governor Ysassi, the Spanish resisted vigorously; the English also, having chosen an unhealthy spot, lost a great many men to fever and other diseases. Had Ysassi been properly supported from Hispaniola, he might well have succeeded against the English, but, denied any kind of support, the best he could do after about two years, was to evacuate most of the Spanish settlers. Runaway Bay, on the north coast, rather ungallantly names the point of his departure. It might be mentioned that the Spanish set their loyal Negro slaves free, who, taking to the hills, made guerilla warfare on the English. This was the beginning of the Maroons, who later continued their hill settlements, resisted the English till late in the Eighteenth century, and are responsible for a number of African and Creole names in Jamaica.

The English took over the present Kingston Harbor and fortified it. As we have seen, Cagway became Passage Fort. The settlement on what had been Careening Cay was renamed Port Royal and this, too, was fortified. They they moved inland, taking over Liguanea plain, renaming the Rio Zautaco the Hope River, after a local plantation. The Spanish names that survived best were those already well known to navigation - thus the names of rivers-Rio Viejo, Rio Nuevo, Rio Bueno and so on. But the

\section{Cassidy}


English maps soon begin to show their own new names - Plantain Garden River, Black River, White River, Cane River and many more. We have also seen some of their transformations such as Wag Water and Ocho Rios. For obvious reasons, since sailing long preceded the construction of roads, coastal names appear first on the maps, and most of them are simply descriptive-Long Reef, Northeast Point, Cow Bay, Alligator River, Old Harbour, Bluefields Bay, Starvegut Bay. Sir Thomas Modiford's survey of 1670 leads to maps with many names not recorded before, with places better located, and with names in actual use.

Soon after the conquest, the English took over the whole island, divided it into parishes, and thereafter their names begin to appear on maps: ten of them saints' names, others named for members of royalty and similar eminences-sometimes both combined. St. Catherine, originally with initial $K$, is thought to reflect not only the saint's name, but that of Catherine of Portugal, the wife of Charles II, who was reigning at the time the parish was formed. Clarendon was named for the first Earl of Clarendon, the chancellor Edward Hyde. Portland, Trelawny, Manchester, and Metcalf (now merged into St. Mary's) were all governors' names, and honorifics. A whole chapter might be written on the names of plantations, usually expressions of hope or satisfaction.

By 1700, when the English had possessed the island for 45 years, it had become a flourishing sugar colony, on the pattern of Barbados. A few older Spanish and Arawak names were kept but on the whole the English went ahead straightforwardly with their own names. The early stages of placename evolution are well illustrated here. Names of Arawak or Carib origin, heard but not always understood by the Spanish but fitted more or less to Spanish pronunciation and orthography, include Jamaica, Navassa, Cagway, Wag-Water, Guanaboa, Oracabessa, Liguanea, and the word cay (in U.S. use key) a common name element.

The Arawak names had come indirectly to the English, whose knowledge of Spanish was evidently poor and certainly casual. They came up with various adaptations, phonetic, folk-etymological, erroneous, but more pronounceable by Englishmen. One well-meant attempt to keep a Spanish form mistakenly converted Chorreras to Ocho Rios. But for the most part, there was no disposition to keep the Spanish forms, as we see in Cagway, Wag-Water, Yallahs; some were abandoned, as Sevilla, Mellilla, Oristan, others half- Englished - Negril, Morant, Port Antonio. The following series of map spellings illustrates not only those tendencies, but 
shows how often mapmakers adapted inaccurately and produced spurious forms as they moved back and forth between Spanish, Italian, French, Dutch, and English with their orthographic differences. Further differences in pronunciation there certainly must have been which the spellings were inadequate to indicate, but sometimes this very contest of polyglot spellings can take the scholar back with some firmness to a probably original form, and possible etymology.

The panoply of Jamaican names and the way they were given reflects typically the process of name-giving in the multilingual Caribbean or Antillean archipelago of the New World.

\section{Placename Forms as Represented on Selected Maps The Name JAMAICA}

Xamayca: c1500 Columbus; 1601 Herrera Xamaica; 1655-6 Cun-

(Iamaica, dall-Pietersz 3; 1704 Charlevoix Xamayca.

Iamayca)

Jamaicha: 1502 Colombo; 1527 Maggiolo.

Jamaiqua: 1502 Canerio; 1502 Cantino; 1513 Ruysch (Unnamed on his 1508 map); 1516 Waldseemüller; 1528 Bordone.

Jamaique: 1555 Le Testu.

Jamaiana: 1507 Waldseemuller - an error, corrected on 1516 map.

Jamaqua: 1507 “Admiral's” map.

Jamaica: 1512 Peter Martyr; 1519 Maggiolo; 1529 Ribero (or (Iamaica, Ribeiro); 1541 Mercator; 1545 Alonso; 1561 Ptolemy; Iamayca) 1576 Porcacchi; 1594 Benzoni; 1597 Wytfliet; 1598 Langenes.

Jamica: $\quad 1540$ Muster Map-an error?

Yamyca: 1621 Iacobsz.

\section{Cassidy}


Yamaica: 1681 Van Keulen.

Jamaica: 1661 Hickeringill (English maps); 1671 Ogilby; 1671

(Iamaica) Seller; 1671 Blome; 1674 Modiford; 1675 Roggeveen; 1678 Slaney; 1680 Visser; 1680 Morden; c1680 Hack; 1689 Thornton; 1696 Lea.

Giamaca: 1690 Coronelli; 1655 Butler: Gemecoe (English correspondence, "phonetic" spellings); 1655 Daniell: Jamico; 1657 Gwakin: Jammaca; 1658 Fleetwood: Jamecah.

\section{Arawak Names (Certain and Probable)}

Navassa: Nabaca-1545 Alonso de Sta. Cruze-cays at the East end; Nauaca - 1561 Ptolemy; Nauaca-1576 Porcacchi; 1597 Wytfliet; Nauaza-1598 Langenes; Mauaxa-n.d. Cundall-Pietersz I.

† Cagway: Caquoy - 1555 Le Testu - site of later Passage Fort; Iaguabo porto - 1576 Procacchi; Caguay - 1596 Benzoni; Iauabo $P^{2}$ - 1597 Wytfliet (Other records: la Guaya); Caguey - 1621 Iacobsz; Laguia - n.d. CundallPietersz I; Caguaya - 1655-6 Cundall-Pietersz III \& IV; Iaguabo - 1655-6 Cundall-Pietersz II; Cagnay - 1681 Van Keulen; Poynt Caggeway - 1661 Hickeringill; Pt. Caggway - 1671 Ogilby; Cageway - 1671 Seller; Cagway - 1680 Visser.

Wag-Water: Guaigata P - 1576 Porcacchi - bay and river; (Also Guayguata 1601 C-P 24); Guiagata P. - 1597 Wytfliet; Wag Water - 1674 Modiford; Aqua Alta B[ay] - 1696 Lea.

Guanaboa: Goneboa - 1661 Hickeringill - inland, No. of Portland (1659 in Pt.; Guanache - 1680 Morden; Guanache 1685 Seller. C-P, 84)

Oracabessa: (Juracabes - 1660 Cundall-Pietersz - document); Hora-Cabesia - 1661 Hickeringill; Ora Cabess - 1671 Seller, Ogilby; Ora Cabessa - 1674 Modiford; Cabesa R 
- 1678 Slaney; Ora Cabesia - 1680 Visser; Cabeca R 1680 Morden; Cabeca R. - 1685 Seller.

Liguanea: Hato de Leguani - 1655-6 Cundal-Pietersz II (Spanish correspondence Cundall-Pietersz p. 84); Legonae 1661 Hickeringill; Lygoney - 1678 Slaney; Liganea 1689 Thornton.

\section{Spanish Names}

†Sevilla: $\quad$ seuilla - 1545 Alba plate 20; Sevilia - 1545 Alba plate 11; Siviglia - 1576 Porcacchi; Seuilla - 1594 Benzoni; Seuilla - 1597 Wytfliet; Sevilla - 1598 Langenes; Sevilla - 1621 Iacobsz; Sevilla - n.d. Cundall-Pietersz I (wrongly placed).

† Melilla: Melilla - 1545 Alba plate 20; Melilla 1576 Porcacchi; Melilla - 1597 Wyfliet (makes it an island); Melille 1621 Iacobsz; Melilla - n.d. Cundall-Pietersz I; Melilla - 1675 Roggeveen.

†Oristan: Oristan - 1545 Alba plate 20 ( area of present Bluefields); oristan - 1545 Alba plate 11; Oristan 1576 Porcacchi; Oristan - 1594 Benzoni; Oristan - 1597 Wytfliet; Oristan - 1598 Langenes; Orestan - n.d. Cundall-Pietersz $I$.

Negril: $\quad$ P del negrillo - 1545 alba plate 20; poincte de negrille - 1555 Le Testu; P del Negrillo - 1576 Porcacchi; P del Negrillo - 1597 Wytfliet; Pta. Negrio - 1621 iacobsz' Pto. del Negrillo - 1655-6 Cundall-Pietersz 3; Puerto Negrill - 1661 Hickeringill.

Morant: $\quad$ P de morante - 1545 Alba plate 20; P de morante -1545 (Point Bay)Alba plate 20; Capo Morante - 1576 Procacchi; (Point Bay)C. Morante -- 1597 Wytfliet; Cabo Morante - n.d. etc.) Cundall-Pietersz I, p. 104; Porto Morante k 1655-6 Cundall Pietersz 3, p. 104; Porto Moran - 1671 Ogilby, Seller, Blome; Morant Pt. 1661 Hickeringill; Pt. Morant - 1689 Thornton. 
Port Antonio:Anton P - 1576 Porcacchi; Anton P - 1597 Wytfliet; P de Antilo - 1621 Iacobsz; P de Anton - 1655-6 Cundall- Pietersz 3, II; P S Antoni - 1661 Hickeringill; P Antonio - 1671 Ogilby.

\section{Spanish Names}

Ocho Rios: (Las Chorreras - 1657-60 Cundall-Pietersz - documents); Ocho Rio - 1671 Ogilby, Seller; Otne Rio 1674 Modiford; Ocho R - 1678 Slaney; Ocho R - 1680 Morden; Ocho R - 1685 Seller; Ocho Rio Port - 1689 Thornton; Ocho Rio B - 1696 Lea.

Yallahs: $\quad$ Aguaia pro. - 1576 Porcacchi; Aguaia prouincia - 1597 Wytfliet; Rio de Ayala - 1655-6 Cundall-Pietersz II; Yallowes - 1661 Hickeringill; Yallowe - 1671 Blome; Yallah r - 1678 Slaney; Yallah R - 1680 Morden; Yallowe - 1680 Visser; Yallah R - 1685 Seller; Yallah 1689 Thornton.

Montego Bay:Monerias - 1655-6 Cundall-Pietersz 3; Montego Bay 1661 Hickeringill; Montego Bay - 1671 Ogilby; Mantega B. - 1675 Roggeveen; Mantica B - 1696 Lea.

$\dagger$ Denotes the name is dead.

\section{University of Wisconsin, Madison}

\section{Works Consulted}

Cundall, Frank, F.S.A. Place-Names of Jamaica Kingston: Institute of Jamaica. 1939.

Cundall, Frank, F.S.A. and Joseph L. Pietersz. Jamaica Under the Spaniards. Kingston: Institute of Jamaica. 1919.

Kapp, Kit S. The Printed Maps of Jamaica up to 1825. Jamaica: Bolivar Press. 1968.

Long, Edward. The History of Jamaica, or General Survey of the Antient and Modern State of that Island. 3 vols. London: Lowndes. 1774.

Other maps chiefly in the American Geographical Society Collection, The University of Wisconsin-Milwaukee Library. 


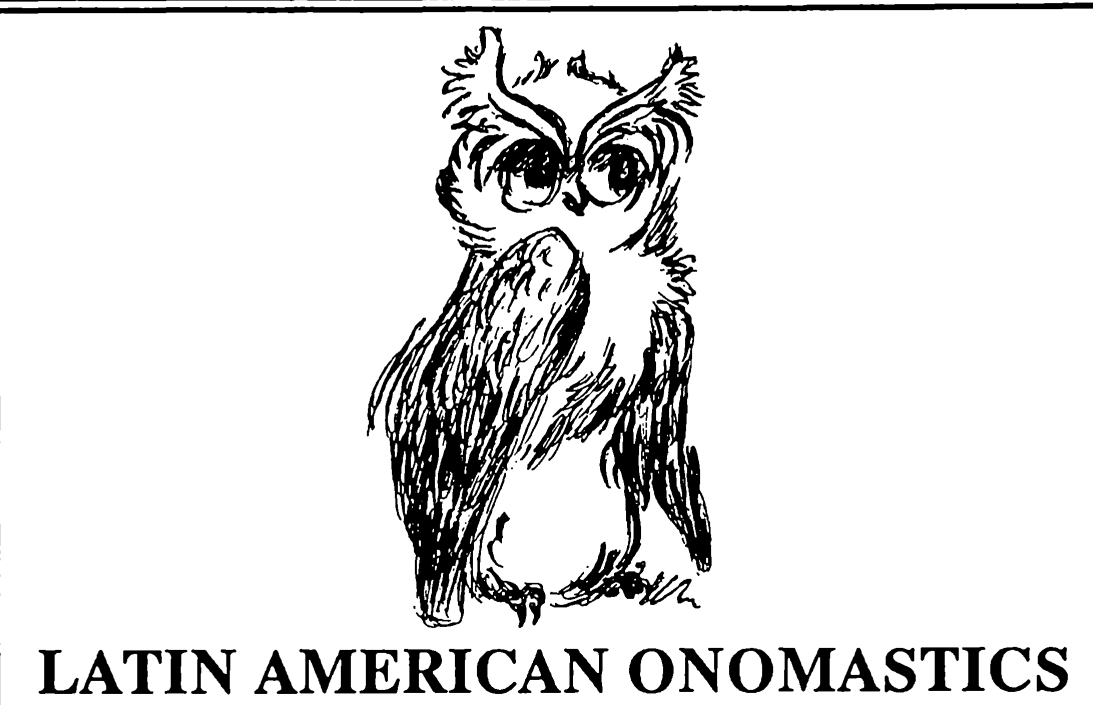

The Library of the University of Texas at El Paso is developing holdings in onomastics, specializing in Latin American Names. Lurline H. Coltharp, past president of the American Name Society, is assisting in the project and is now asking the members of the Society for help.

If you would like to have a brochure about holdings that should be included, please write to:

\section{Lurline H. Coltharp \\ 4263 Ridgecrest \\ El Paso, TX 79902}

In addition, if you have any books or journals that you would like to contribute, please write first, either to Professor Coltharp or directly to the library:

Hatsuyo K. Hawkins

The Library

The University of Texas at El Paso

El Paso, TX 79968 